- Onto Kusumo dan Dewi Cahyani Puspitasari

Departemen Sosiologi, FISIPOL, Universitas Gadjah Mada

\title{
POTRET DAN DINAMIKA WIRAUSAHA MUDA KREATIF KALIABU
}

\begin{abstract}
This study aimed to understand the emergence of the creative class in the context of youth villager. This study used a case study approach by taking the case of the emergence of graphic designers at Kaliabu Village, Magelang Regency. This study used the theory of Creative Class and Youth to explain the dynamics of the emergence of the creative class in Kaliabu. Opportunities in the form of professional graphic designers who comes in line with the current socio-economic changes currently utilized by the younger generation Kaliabu. These changes are related to the economic system based on information technology, progress and financial services industry, the emergence of the company with a flexible system, global supply chains, as well as the process of globalization. These things are external factors that allow graphic designers in Kaliabu Village to carry out cross-country service transactions in online graphic design marketplaces such as 99design.

The external change then responded with passion of high exploration by youths Kaliabu. The success of one of the residents in Kaliabu by winning the online design contest fortunately inspire other youths. The learning process occurs among Kaliabu youth. Ultimately in 2012 in the village of Kaliabu already has two hundred young people who become a graphic designer. They are embodied in a community called as Rewo-Rewo. Their function as provider of graphic design and the relations on aspects of talent, technology, and tolerance explaining they are parts of the creative classes. The conclusion of this study showed that the rise of the creative class in the form of hundreds of graphic designers in Kaliabu is a result of the dynamics of youth Kaliabu in response to socio-economic changes. The graphic design of the logo brought economic benefits to them.
\end{abstract}

Keywords: Kaliabu Graphic Designer, Creative Class, Youth

\section{PENDAHULUAN}

Desainer kampung" (village designer) adalah salah satu judul film yang menjadi finalis dalam kompetisi film dokumenter Eagle Award. Kompetisi film dokumenter ini digagas oleh salah satu station TV nasional. Film ini memotret keberadaan ratusan desainer grafis yang berada di Desa Kaliabu Kabupaten Magelang. Para desainer grafis ini terwadahi dalam suatu komunitas desainer grafis yaitu Rewo-Rewo. Film dokumenter tersebut dibuat pada tahun 2012. Para desainer grafis di Kaliabu telah seringkali memenangkan kompetisi pembuatan logo di internet. Kompetisi ini diadakan oleh berbagai perusahan baik dalam maupun luar negeri yang membutuhkan logo. Dari hasil tersebut, para desainer grafis di Kaliabu telah menghasilkan belasan bahkan puluhan juta rupiah.

Kemunculan kegiatan desain logo di Kaliabu digerakkan oleh orang-orang yang bekerja dengan mengandalkan kekuatan menciptakan ide dan hal-hal baru. Mereka bekerja dengan mengandalkan kemampuan untuk menciptakan konten-konten grafis untuk mendapatkan faedah ekonomi. Melihat fenomena tersebut peneliti ingin mengkaji 
kemunculan ratusan desainer Kaliabu dengan menggunakan perspektif kelas kreatif Richard Florida dalam menciptakan ekonomi kreatif. Penjelasan Florida (2002) terkait kelas kreatif adalah sebagai berikut " the distinguishing characteristic of the class creative is that its members engage in work whose function is to create meaningful new form". Florida menjelaskan bahwa kelas kreatif adalah mereka yang bekerja dengan membuat hal-hal baru dan mereka mendapatkan faedah ekonomi dari hal-hal baru yang mereka buat.

Jika melihat deskripsi umum mengenai kelas kreatif Florida, maka ratusan desainer grafis kaliabu dapat dikategorikan sebagai kelas kreatif. Hal ini karena para desainer grafis Kaliabu mendapatkan faedah ekonomi dari desain-desain grafis yang mereka buat. Namun demikian, apakah benar ratusan desainer grafis Kaliabu merupakan kelas kreatif yang dibayangkan Florida. Mengingat kemunculan ratusan desainer grafis Kaliabu hadir dalam konteks masyarakat desa. Hal ini tentunya berbeda, ketika kita mencermati bahwa teori kelas kreatif Florida hadir dalam konteks masyarakat yang sangat bias kota. Sementara itu, ratusan desainer grafis Kaliabu muncul dalam konteks masyarakat pedesaan. Pendapat Florida mengenai kemunculan kelas kreatif ini cukup logis, mengingat masyarakat kota lebih memiliki akses terhadap pendidikan, pelatihan, infrastruktur yang memadai, dekat dengan pusat perekonomian sehingga mereka dapat melakukan interaksi dengan berbagai macam orang yang memiliki karakter berbeda-beda. Hal-hal ini memungkinkan seseorang mengembangkan kemampuan dan keterampilan. Namun, bagaimana jika kelas kreatif ini tumbuh subur di masyarakat desa. Hal ini tentunya menjadi kajian yang menarik dalam kajian mengenai kelas kreatif yang masih didominasi dalam konteks masyarakat kota.

Penelitian dilakukan untuk menjawab kemunculan kelas kreatif dalam konteks masyarakat Desa Kaliabu khususnya yang gagasan inovatifnya dilakukan oleh pemuda. Hasil dari penelitian ini akan mengidentifikasi dinamika proses kemunculan kelas kreatif muda yang menjadi pioneer wirausaha muda kreatif Kaliabu. Profil pemuda Kaliabu diidentifikasi dengan menggunakan kerangka konsep kelas kreatif yang menghasilkan karakteristik unik dari peran inovatif pemuda di Kaliabu.

\section{METODE PENELITIAN}

Penelitian ini menggunakan jenis penelitian kualitatif dengan pendekatan studi kasus. Metode dan pendekatan ini dipilih karena penelitian ini bertujuan untuk memahami proses dan aspek yang melatarbelakangi kemunculan kelas kreatif di Kaliabu. Tujuan penelitian ini bersifat unik dan hanya ditujukan pada pengalaman suatu komunitas yaitu Desainer Kampung Kaliabu. Oleh karena itu, penelitian ini menggunakan desain pendekatan penelitian yaitu studi kasus. Yin (1996) menjelaskan studi kasus adalah salah satu dari jenis metode penelitian sosial yang digunakan untuk memahami suatu peristiwa yang unik secara holistik pada suatu fenomena sosial. Hasil dari suatu penelitian studi kasus tidak bersifat umum (general) akan tetapi spesifik pada fenomena yang terjadi pada objek penelitian saja.

Pada tahap pengumpulan data ada tiga teknik pengumpulan data yaitu observasi, studi dokumentasi dan wawancara. Observasi atau pengamatan merupakan kegiatan pengumpulan data dengan mengamati secara natural objek penelitian. Peneliti ini secara langusung melihat kondisi fisik dan kehidupan sehari kehidupan desainer grafis Kaliabu. Peneliti mengobserbasi kondisi kampung Kaliabu, kondisi rumah desainer grafis Kaliabu dan kondisi sarang Komunitas Rewo-rewo. Selain melakukan observasi secara fisik, peneliti juga melakukan obeservasi pada akun grup media sosial komunitas desain 
grafis yaitu akun grup Facebook Rewo-rewo Art. Peneliti meminta agar dimasukkan dalam grup tersebut. Hal ini dilakukan karena banyak sekali aktivitas komunitas desainer grafis Kaliabu yang dikomunikasikan dan didiskusikan melalui media sosial. Selain observasi, penelitian ini juga menggunakan teknik wawancara dengan tiga kelompok utama. Pertama adalah kelompok yang merepresentasikan desainer grafis Kaliabu. Kedua adalah kelompok yang merepresentasikan pemerintah lokal. Ketiga adalah kelompok yang merepresentasikan tokoh masyarakat. Setelah data dirasa cukup peneliti menyusun laporan penelitian. Laporan disusun bersamaan dengan proses analisis data yang ditemukan di lapangan.

Analisa data pada penelitian ini menggunakan beberapa tahapan yaitu, reduksi data, penyajian data, dan penarikan kesimpulan (Matthew and Huberman 2009). Reduksi data atau coding adalah tahap pertama dalam analisis data kualitatif. Reduksi data diartikan sebagai proses menyeleksi data yang telah dikumpulkan dilapangan. Data-data yang telah dikumpulkan dipilih dan dikelompokkan sesuai dengan preposisi yang akan dikembangkan. Sementara data yang dianggap tidak penting dapat ditinggalkan. Tahap penting selanjutya adalah penyajian data. Tahap ini merupakan tahap menyusun dan memformulasikan data agar memungkinkan adanya penarikan kesimpulan.

\section{KERANGKA KONSEP}

Penelitian ini menggunakan konsep utama kelas kreatif dari Richard Florida dan pemuda. Berikut penjelasan dari masingmasing konsep:

\subsection{Kelas Kreatif}

Menurut Florida (2002) kelas kreatif merupakan "the distinguishing characteristic of the class creative is that its members engage in work whose function is to create meaningful new form". Florida men- jelaskan bahwa kelas kreatif adalah mereka yang bekerja dengan membuat hal-hal baru dan mereka mendapatkan faedah ekonomi dari hal-hal baru yang mereka buat. Florida (2002) menambahkan bahwa

\begin{abstract}
"Seluruh umat manusia adalah kreatif, apakah ia seorang pekerja di pabrik kacamata atau seorang remaja di gang yang sedang membuat musik hip hop. Namun perbedaannya adalah pada statusnya, karena ada individu-individu yang secara khusus bergelut di bidang kreatif dan mendapat faedah ekonomi secara langsung dari aktivitas itu".
\end{abstract}

Ia juga mengungkapkan terdapat beberapa bidang yang termasuk dalam kelas kreatif di antaranya adalah peneliti, pengajar, insinyur, arsitek, desainer, pendidik, artis, musisi dan lain sebagainya.

Lebih lanjut lagi, Florida menjelaskan tentang ciri dari kelas kreatif yaitu meliputi technology, talent dan tolerant yang kemudian dikenal dengan konsep 3T. Pertama, teknologi merupakan alat yang diciptakan untuk membantu memenuhi kebutuhan manusia. Kedua, talenta (talent) yaitu kemampuan individu untuk menciptakan konten, gagasan dan hal-hal baru yang bernilai. Ketiga, toleransi adalah kemauan dan sikap keterbukaan untuk menjalin hubungan dengan siapapun. Semakin toleran seseorang semakin ia tidak membatasi hubungan, kerjasama, dan pembentukan dengan siapapun.

Selain karakteristik di atas, Florida (2002) juga menjelaskan karakteristik kualitas tempat yang memungkinkan tumbuhnya kelas kreatif. Pertama, kedekatan dan keberagaman pasar kerja yaitu kelas kreatif cenderung memilih tempat yang memiliki peluang kerja beragam. Kedua, gaya hidup yaitu kelas kreatif cenderung memiliki karakteristik selera hidup yang unik. Mereka terkadang lebih rela berpindah pekerjaan meski dengan gaji yang lebih rendah untuk mendapatkan life style yang mereka inginkan. Ketiga, interaksi sosial yaitu kelas kreatif cenderung memilih tempat 
dimana ia dapat bertemu dan berinteraksi dengan orang-orang yang mereka ingin temui. Keempat, keberagaman dan perbedaan yaitu kelas kreatif cenderung memilih tempat yang memliki tingkat heterogenitas yang tinggi.

\subsection{Pemuda}

Pemuda atau kaum muda (youth) jika dimaknai secara harfiah merupakan sekelompok manusia yang berada pada tahapan jenjang perkembangan antara tahap anak-anak dan dewasa. Secara umum, periode transisi dari masa kanak-kanak (childhood) menuju kedewasaan ini cenderung penuh dengan dinamika dan fluktuasi seiring perubahan lingkungan sosialnya (Azca et al 2011). Oleh karena itu, pemuda dianggap kelompok yang penuh energi dan responsif terhadap adanya perubahan sosial. Ada dua pendekatan yang dapat digunakan untuk memahami pemuda yaitu pendekatan secara biologis dan pendekatan secara sosial. Pendekatan biologis lebih melihat pemuda dari segi umur. Misalnya dalam Undang-Undang No. 40/2009 Tentang Kepemudaan, menjelaskan bahwa pemuda adalah warga negara yang memasuki periode penting masa pertumbuhan yang digolongkan dalam kelompok umur 16-30 tahun. Pendekatan biologis juga digunakan World Health Organization (WHO) untuk memahami pemuda. Menurut WHO Pemuda adalah seseorang yang memiliki umur 10 hingga 24 tahun. Dari segi sosial, pemuda dapat dipahami sebagai kelompok masyarakat yang sedang dalam masa transisi baik menuju ke tahap kedewasaan maupun pada domain pendidikan, pekerjaan, dan pernikahan (Sutopo dan Azca 2013).

\section{TEMUAN DAN ANALISIS}

\subsection{Karakteristik Sosial Masyarakat Kaliabu}

Penelitian ini menarik dari sisi kajian untuk mengamati potret dan dinamika proses dari kemunculan kelas kreatif yang unik karena terjadi di wilayah perdesaan. Studi ini menjadi berbeda dari anggapan Florida (2002) bahwa kelas kreatif cenderung berkembang pada tempat yang memiki ciri sebagai berikut: tempat yang mendukung gaya hidupnya, mampu menampung hasil karya mereka, tempat-tempat yang memiliki kedekatan dengan pasar, tempat yang memiliki kualitas seperti tersedia institusi pendidikan (university hub) yang menerapkan 3T (teknologi, talenta, toleran), tempat yang memiliki gedung-gedung sebagai pusat seni, tempat dengan ketersediaan ruang publik, dan tempattempat ini menjadi wahana bertemunya orang-orang yang memiliki keragaman dan latar belakang yang berbeda. Pembahasan ini menganalisis lebih lanjut mengenai kualitas tempat yang dimiliki Kaliabu. Aspek tempat ini menjadi penting untuk identifikasi karakteristik kelas kreatif ditinjau dari lokasi perdesaan yaitu pada konteks sosial yang dapat memunculkan kreativitas warga masyarakatnya.

Pembahasan awal dimulai dari aspek institusi pendidikan yang ada di Desa Kaliabu. Dari hasil olah data primer penelitian, di Desa Kaliabu tidak terdapat institusi pendidikan formal yang memfasilitasi pengembangan kemampuan desain grafis di Kaliabu. Di Kaliabu hanya terdapat 4 taman kanak-kanak (TK), 3 Sekolah Dasar (SD), dan 2 sekolah menengah (BPS 2016). Tidak ada institusi pendidikan formal baik pada jenjang sekolah menengah kejuruan (SMK) atau perguruan tinggi. Di Kabupaten Magelang sebenarnya terdapat beberapa perguruan tinggi seperti Universitas Muhammadiyah Magelang, Universitas Tidar Magelang, dan Politeknik Magelang. Namun, perguruan-perguruan tinggi tersebut juga tidak memiliki spesifikasi bidang studi dalam bidang Desain Grafis. Selain itu, jika dicermati jarak Desa 
Kaliabu dengan pusat Kabupaten Magelang tergolong cukup jauh. Perbedaan ini menunjukkan adanya hal keterbatasan dalam aspek keberadaan institusi pendidikan dalam konteks kemunculan kelas kreatif di Kaliabu.

Kedua, aspek kedekatan dengan pasar yang juga menjadi aspek penting dalam kemunculan kelas kelas kreatif. Bila dilihat dari kedekatan dengan pasar (fisik) yaitu terdapat infrastruktur pasar yang terletak di Desa Kaliabu meski masih termasuk kategori pasar tradisional dengan jangkauan konsumen terbatas karena hanya warga desa di sekitar Kaliabu. Namun, pasar ini bukan menjadi pasar bagi produk-produk desainer grafis di Kaliabu. Selain itu, di pasar tersebut juga tidak ada satupun desainer grafis Kaliabu yang membuka toko atau studio untuk menawarkan jasa desainer grafis. Dari sisi lain, bila dilihat dari kedekatan Desa Kaliabu dengan pusat Ibukota Kecamatan maupun Ibukota Kabupaten, Desa Kaliabu tergolong desa yang memiliki jarak paling jauh dengan pusat kota.

Ketiga, aspek gaya hidup, para desainer grafis tidak terlalu membutuhkan lingkungan spesifik dalam mendukung gaya hidup mereka. Kondisi Kaliabu bagi mereka sudah cukup nyaman menjadi tempat untuk tinggal. Hal ini karena kebanyakan mereka lebih dulu tinggal di Kaliabu sebelum mereka menjadi seorang desainer grafis. Perubahan gaya hidup yang nampak adalah terkait dengan tingkat konsumsi yang semakin tinggi seiring pendapatan mereka yang meningkat. Berikut pendapat salah satu informan:

"Perubahan yang saya lihat dari pemua-
pemuda di Kaliabu adalah tingkat
konsumsinya yang semakin tinggi" (Imam,
wawancara 2016)

Dari pendapat di atas menunjukkan bahwa peningkatan konsumsi nampak pada kepemilikan mobil oleh beberapa pemuda di Kaliabu. Mobil-mobil ini didapat dari usaha mereka dalam menjalani profesi desainer grafis. Gaya hidup lain yang saat ini sedang populer dikalangan pemuda Kaliabu adalah penggunaan rokok elektrik. Saat ini di antara para desainer Kaliabu muncul gaya rokok dengan menggunakan rokok elektrik.. Gaya hidup seperti ini masih diperbolehkan juga di Kaliabu. Kebanyakan para desainer grafis masih mempertahankan nilai dan norma dalam menjalani gaya hidup. Selain itu, beberapa waktu yang lalu, di kalangan pemuda Kalabu sedang ramai-ramainya mengoleksi burung. Burung-burung ini dikoleksi untuk diikutsertakan dalam lomba kicauan burung. Kebanyakan dari mereka masih merasa Kaliabu sebagai tempat yang nyaman. Ada sebagian warga Kaliabu yang pindah ke kota. Namun hal-hal seperti itu bukan karena adanya tuntutan gaya hidup yang tidak bisa diakomodasi di Kaliabu. Kebanyakan desainer Kaliabu tidak mempersoalkan kualitas tempat Kaliabu dalam mendukung gaya hidup mereka

Keempat, keragaman interaksi yaitu mengacu pada Florida (2002) bahwa keberagaman interaksi adalah energi bagi kelas kreatif untuk menciptakan inovasi. Dalam konteks Kaliabu, kondisinya ada pada lokasi yang jauh dari pusat ekonomi, pendidikan, wisata, dan pemerintahan. Oleh kerena itu, tidak banyak orang yang kemudian ingin mengunjungi atau tinggal di Kaliabu. Lalu lintas migrasi dan tingkat homogenitas warganya masih rendah. Kebanyakan penduduk yang tinggal di Kaliabu adalah warga asli Kaliabu. Adapun perpindahan penduduk baik keluar ataupun masuk ke Kampung Kaliabu lebih banyak disebabkan oleh faktor pernikahan. Melihat hal tersebut maka nampak terjadi keterbatsan pada kualitas tempat Kaliabu dalam hal keberagaman interkasi dengan kemunculan kelas kreatif di Kaliabu.

Kelima, ruang publik dan interaksi yaitu untuk wilayah Desa Kaliabu sendiri tidak banyak ruang publik yang digunakan sebagai ruang bertemu para desainer grafis Kaliabu. Ada beberapa warung makan yang ada, namun warung makan ini berfungsi 
sebagai ruang publik bagi warga Kaliabu secara umum. Beberapa di antara para desainer grafis Kaliabu seringkali bertemu dan kumpul-kumpul di rumah salah satu dari mereka. Berikut pendapat salah satu informan:

"Kita jarang nongkrong di luar, kita lebih sering kumpul-kumpul di salah satu rumah teman" (Handika, wawancara 2016).

Ruang publik adalah wahana penting bagi para kelas kreatif, seperti diungkapkan Florida keberadaan bar dan tempat-tempat makan sebagai tempat berkumpulnya kelas kreatif sangat penting bagi mereka. Di ruang publik seperti akan muncul pembicaraanpembicaraan yang santai sampai ke hal-hal yang serius. Hal ini terjadi di Yogyakarta. Sebagai kota pelajar banyak bermunculan kafe, rumah makan, angkringan, dan berbagai tempat yang memang hadir untuk memenuhi kebutuhan mahasiswa dalam melakukan pertemuan. Tidak hanya mahasiswa, tempat-tempat tersebut juga digunakan orang-orang yang sedang sudah bekerja untuk melakukan pertemuan.

Terkait dengan keberadaan infrastruktur, Kaliabu adalah kampung yang sederhana. Tidak ada gedung atau tempattempat lain sebagai pusat seni, budaya, maupun kreativitas. Desa Kaliabu juga tidak tersedia gedung serbaguna. Padahal keberadaan gedung serbaguna sudah lumrah dimiliki oleh desa-desa saat ini. Bagi seorang desainer grafis tentunya keberadaan tempattempat seperti itu menjadi penting. Tempattempat tersebut biasanya digunakan untuk memamerkan hasil karya-karya mereka.

Di Kaliabu terdapat kesenian jatilan. Kesenian sering di pertontonkan dalam kegiatan seperti rangkaian acara 17 tahun. Namun kesenian ini dipraktekkan di tempattempat yang tidak ditentukan. Begitupula infrastruktur yang terkait dengan desain grafis. Tahun 2012 saat pertama kali desainer grafis muncul di Kaliabu, tidak ada banyak infrastruktur yang mendukung keberadaan desainer grafis. Pada awal kemunculannya para pemuda Kaliabu mengalami beberapa kendala dalam menjalani profesinya sebagai desainer grafis. Beberapa kendala di antaranya seperti terbatasnya komputer yang bisa dipakai, sulitnya akses internet, dan aliran listrik yang sering mati. Hal-hal tersebut cukup menjadi kendala bagi para pemuda Kaliabu dalam belajar sekaligus bekerja sebagai desainer grafis. Dari aspek ini, maka nampak pula keterbatasan kualitas tempat yang dimiliki Kaliabu dengan kualitas tempat yang disyaratkan oleh Richard Florida yang konsen pada masyarakat kota (urban).

\subsection{Kelas Kreatif Muda Kaliabu: Latar Kemunculan dan Proses Inovatif}

Jika dilihat dari segi kualitas tempat yang dimiliki Kalibu maka jelas Kaliabu tidak memiliki syarat sebagai tempat yang memungkinkan munculnya Kelas kreatif termasuk desainer grafis. Namun demikian, faktanya di Kaliabu muncul ratusan desainer grafis yang karyanya sudah sering menang dalam kompetensi desain pada level internasional. Dalam catatan prestasi dan pemberitaan nampak pula banyak pihak yang mengapresiasi apa yang terjadi di Kaliabu. Lalu pertanyaan yang muncul adalah mengapa hal ini terjadi di Kaliabu. Mengapa ada ratusan desainer grafis yang muncul dalam konteks masyarakat desa. Sub-bab ini akan mencoba menguraikan bagaimana hal tersebut bisa terjadi. Bab ini akan mencoba menjelaskan ada perubahan ekternal di Kaliabu yang sangat mempengaruhi kemunculan kelas kreatif di desa ini. Perubahan eksternal tersebut adalah keadaan masyarakat kontemporer yang ditandai dengan hal-hal sebagai berikut : 1) Adanya dominasi teknologi informasi dalam segala aspek aktivitas masyarakat 2) Pesatnya perkembangan industri jasa dan keuangan di tengah-tengah masyarakat 3) Pemenuhan kebutuhan masyarakat melalui rantai suplai global 4) Munculnya perusahaan dengan sistem yang fleksibel baik dalam produksi 
maupun ketenagakerjaan 5) Proses globalisasi di tengah-tengah masyarakat

\subsubsection{Teknologi Informasi}

Pengaruh pertama adalah adanya keterkaitan yang kuat antara kehidupan masyarakat dengan teknologi informasi. Hal ini dialami oleh para desainer grafis Kaliabu. Keberadaan teknologi informasi adalah sesuatu yang mutlak bagi para desainer Kaliabu. Mengapa demikian? Jika ditarik ke belakang, peran teknologi informasi sudah hadir sebagai sarana penunjangan pengembangan kemampuan desain para desainer grafis Kaliabu. Berbagai informasi baik tulisan, video, maupun informasi yang mereka pelajari di intenet hanya mungkin mereka akses melalui teknologi infomasi. Selain itu, melalui teknologi informasi pula mereka dapat berjejaring dengan anggota desainer grafis yang lain baik di tingkat kampung, tingkat kota, tingkat nasional, maupun berbagai bentuk jaringan desainer grafis yang lain. Jaringan yang terbentuk di dunia maya ini sangat penting karena di dalam jaringan tersebut terjadi proses pertukaran informasi mengenai desainer yang sangat penting bagi perkembangan kemampuan mereka. Keberadaan teknologi informasi memungkinkan masyarakat Kaliabu menjadi seorang desainer grafis tanpa melalui proses pendidikan formal.

Gambar 1 Desainer Grafis Kaliabu dan Teknologi Informasi

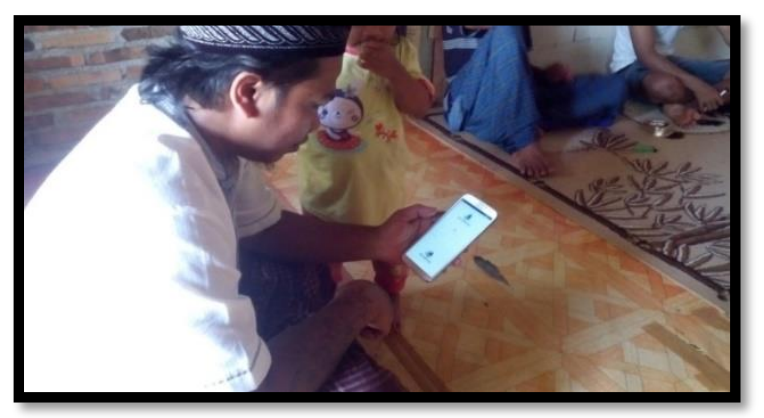

Sumber : Dokumentasi peneliti

Selain berperan dalam aspek pengembangan talenta dan kemampuan, teknologi informasi juga sangat membantu desainer grafis Kaliabu dalam melakukan transaksi jasa. Hampir keseluruhan transaksi jasa yang dilakukan dengan bantuan teknologi informasi. Pekerjaan desainer grafis di Kaliabu dimulai dengan membuat akun sebagai seorang desainer grafis di salah satu situs web di internet. Setelah itu, mereka mencari kontes logo yang akan mereka ikuti. Kebanyakan mereka mengikuti kontes logo di situs 99.desain.com. Dimana setiap hari ada ratusan permintaan logo yang dikonteskan di situs ini.

\section{Kemajuan Industri Jasa dan Keuangan}

Faktor eksternal kedua yang berpengaruh pada kemunculan desain grafis di Kaliabu adalah adanya kemajuan yang pesat industri-industri yang bergerak di bidang jasa dan keuangan. Salah satu bidang jasa yang cukup berkembang pada saat ini adalah desainer grafis. Seorang desainer grafis adalah seseorang yang mampu menciptakan berbagai konten dan gambar grafis. Desain grafis juga sering disebut sebagai desain komunikasi visual. Berbagai perusahan dan organisasi seringkali menggunakan jasa seorang desain grafis untuk mengkomunikasikan sesuatu kepada masyarakat. Misal dalam hal logo, hampir semua perusahaan atau organisasi membutuhkan logo untuk menunjukkan identitas dan image mereka.

Gambar 2 Halaman Depan situs 99design.com

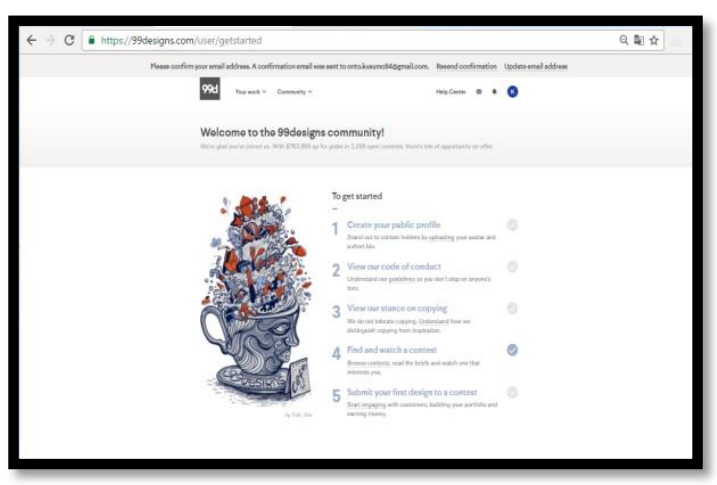

Sumber : 99design.com

Perkembangan desainer grafis di Kaliabu juga tidak lepas dari kebutuhan 
desainer grafis yang semakin banyak. Hal ini dapat dilihat dari banyaknya situs web yang menyediakan kontes logo bagi para desainer. Beberapa di antaranya seperti 99.desain.com, logoturnamen.com, dan lain sebagainya. Hal ini menunjukkan bahwa kemunculan desainer grafis di Kaliabu tidak lepas dari perkembangan kebutuhan akan industri jasa desain yang besar di masyarakat. Jumlah permintaan desain di situs 99design.com mencapai delapan ratus hingga ribuan. Situs 99 design dapat disebut pula perusahaan pengelola marketplace online. Perusahaan menyediakan suatu tempat bertemunya penjual dan pembeli secara online. Namun, perusahaan ini mengkhususkan diri di bidang desain. Hampir seluruh desainer grafis di Kaliabu memulai karir di situs 99design.com, sebagaimana dijelaskan:

\section{"Hampir semua desainer grafis di Kaliabu mengukuti kontes di 99 desain, namun beberapa juga sudah mulai mencoba di situs- situs yang lain” (Haki, wawancara 2016)}

Selain karena adanya permintaan yang besar mengenai desain grafis, perkembangan desainer grafis juga sangat terbantu oleh kemudahan transaksi lintas negara. Saat ini hadir berbagai perusahaan yang memberikan layanan transaksi keuangan lintas negara. Beberapa layanan transaksi lintas negara diantara adalah Paypal, westren union, dan berbagai layanan kartu kredit. Kebanyakan desainer grafis di Kaliabu menggunakan Paypal dalam melakukan transaksi. Paypal bekerjasama dengan bank-bank nasional seperti BRI, BNI, atau Mandiri. Bank-bank ini sudah ada di pusat Ibukota Salaman. Hal ini sangat memudahkan Kaliabu dalam melakukan transaksi jasa desain grafinya. Meski demikian, warga Kaliabu tetap harus menempuh jarak sekitar $7 \mathrm{~km}$ untuk menuju ke Ibukota Kecamatan Salaman.

\section{Perusahaan Dengan Sistem Fleksibel}

Faktor eksternal ketiga adalah munculnya banyak perusahaan dengan sistem yang fleksibel dalam produk, cara kerja dan ketenagakerjaan. 99.desain.com adalah perusahaan yang mengelola situs yang sebagai penghubung antara desainer grafis dan klien. Perusahaan ini bergerak secara multinasional dan sistem yang fleksibel. Setiap orang dapat ikut berkompetisi di dalam situs dan mendapat status sebagai pekerja freelancer. Sistem kerja di 99design menggunakan sitem crowdsourcing. Cara kerja crowdsourcing adalah cara menyelesaikan suatu proyek atau pemintaan dengan manawarkan kepada banyak orang. Jadi proyek desain atau permintaan desain yang masuk dilayani melalui usaha banyak orang. Para peminta jasa atau biasa disebut Contest Holder $(\mathrm{CH})$ dapat memilih desain mana yang paling sesuai dengan kebutuhan mereka.

99design tidak mengharuskan desainer grafis yang tergabung dalam situsnya memiliki catatan akademik sebagai desainer profesional. Sistem kerja seperti itu membuat masyarakat Kaliabu dapat mengakses pekerjaan sebagai desainer grafis di Kaliabu. Tentunya sangat sulit bagi desainer grafis Kaliabu jika sistem kerja harus menuntut ijazah sebagai seorang profesional di bidang desain grafis. Situs 99design sendiri menerapkan sistem yang bersifat fleksibel dalam sisi produknya. 99design memang memfokuskan pada pasar desain grafis. Namun jenis produk desain juga bermacammacam. Ada lima jenis produk desain yang ditawarkan yaitu logo dan tanda pengenal, web dan aplikasi desain, desain bisnis, iklan desain, desain baju, barang dagangan, desain seni, ilustrasi, serta buku dan cover majalah.

\section{Rantai Suplai Global}

Selanjutnya faktor eksternal keempat adalah adanya rantai suplai global dalam upaya pemenuhan kebutuhan masyarakat. Dalam konteks masyarakat Kaliabu, hal ini dapat dilihat dari transaksi jasa yang dilakukan para desainer grafis Kaliabu. Mereka melakukan transaksi lintas negara dengan menggunakan dolar sebagai mata uang acuan transaksi mereka. Menurut 
keterangan penggiat komunitas desainer Kaliabu, kebanyakan klien mereka justru berasal dari luar negeri seperti Eropa, Cina, Amerika, Australia, dan Singapura. Kebanyakan klien mereka merupakan perusahaan yang membutuhkan logo baru untuk menunjukkan identitas mereka. Pertemuan antara desainer dan klien dilakukan di dunia maya. Baik klien maupun desainer terikat regulasi yang diatur perusahaan yang pengelola website.

\section{Globalisasi}

Faktor eksternal terakhir adalah globalisasi. Globalisasi adalah proses interkoneksi yang terus meningkat di antara berbagai masyarakat sehingga kejadiankejadian yang berlangsung di sebuah negara mempengaruhi negara dan masyarakat lainya. Dunia yang terglobalisasi adalah dunia dimana peristiwa-peritiwa politik, ekonomi, budaya, dan sosial semakin terjalin erat dan merupakan dunia dimana kejadiankejadian tersebut berdampak semakin besar (Rais 2008). Proses ini terjadi pada desainer grafis Kaliabu. Sebagai sebuah komunitas lokal tentunya sulit membayangkan masyarakat Kaliabu mampu melakukan transaksi lintas negara pada masa-masa sebelumnya. Namun, hal ini terjadi saat ini karena dorongan proses globalisasi yang menghubungkan masyarakat di berbagai belahan dunia. Saat melayani klien, mereka tidak hanya melakukan pertukaran jasa, akan tetapi terjadi pula pertukaran kebudayaan antar-satu dengan yang lain.

\subsection{Pemuda Kaliabu sebagai Motor Penggerak Perubahan Inovatif Desa}

Pembahasan ini fokus pada gambaran peran pemuda dalam proses inovatifnya dalam melakukan perubahan inovatif yang menjadi salah satu unsur dari inovasi sosial khususnya di Desa Kaliabu. Hal ini tentu kita pahami bersama bahwa saat terjadi perubahan di dalam suatu komunitas masyarakat, akan selalu terdapat aktor yang mendorong perubahan itu terjadi. Aktor tersebut sering dikenal dengan istilah agent of change yaitu aktor yang mendorong perubahan Kaliabu sebagai komunitas masyarakat desa hingga menyesuaikan perubahan yang terjadi di luar Kaliabu. Hal ini dapat dijawab dengan menelusuri kemunculan bagaimana awal kemunculan ratusan desainer grafis di Kaliabu. Menurut pengakuan desainer grafis senior di Kaliabu, sebenarnya perkembangan desainer grafis di Kaliabu bukan yang pertama di daerah Magelang. Di Magelang sudah banyak para profesional di bidang desainer grafis. Namun demikian, keberadaan para desainer saat itu tidak menyatu dan membentuk komunitas. Mereka berkarir secara individual seperti di kota-kota. Hal ini berbeda dengan Kaliabu, para desainer grafis Kaliabu membangun komunitas dan membentuk semacam cluster kawasan desainer grafis di desa Kaliabu

Perkembangan profesi desainer grafis di Magelang kemudian dicermati oleh Aqib dan Very, dua pemuda Kaliabu yang pertama kali mengenalkan profesi desainer Kaliabu kepada pemuda-pemuda Kaliabu. Sebelum tahun 2011 profesi desainer grafis belum berkembang di Kaliabu. Profesi tersebut mulai berkembang dari keberadaan warnet yang didirikan oleh Aqib. Di awal berdirinya warnet banyak digunakan warga dan pemuda Kaliabu sebagai media hiburan. Hal itu berubah, ketika pada suatu hari Very menceritakan tentang keberhasilan saudaranya menjadi seorang desainer grafis kepada Aqib. Very menceritakan kepada Aqib, saudaranya yang berada di Magelang kota berhasil mendapatkan uang dengan nominal dolar melalui kontes logo yang ada di situs 99desain.com. Setelah mendengarkan penjelaskan dengan seksama kemudian Aqib dan Very bersepakat untuk mempelajari desainer grafis. Selang seminggu setelah mereka mempelajari desain, Aqib memenangkan kontes dengan nominal 180 dolar. 
Akhirnya ia memutuskan untuk menutup warnetnya agar ia dapat fokus menggeluti desain grafis. Beberapa teman dekat Aqib di kampung mengikuti jejak Aqib untuk menggeluti desainer grafis. Awal kali ditawari banyak yang merasa tidak mampu. Berbeda dengan Aqib, kebanyakan dari mereka sangat minim menggunakan alat teknologi informasi. Namun dengan telaten, Aqib yang saat itu juga sedang belajar mendesain, mengarahkan beberapa teman dekatnya sampai bisa membuat desain logo. Proses itu akhirnya berbuah hasil, pada bulan ketiga semenjak mereka belajar desain, teman-teman dekat Aqib mulai memenangkan kontes. Kabar kemenangan Aqib dan beberapa teman dekatnya mulai berkembang di kalangan pemuda Kaliabu. Kemudian banyak pemuda Kaliabu yang belajar desain antara satu dengan yang lain. Pemuda yang sudah bisa mengajari pemuda lain yang belum bisa. Proses seperti ini terus berlangsung hingga saat ini.

\subsubsection{Generasi awal Desainer Grafis Kaliabu}

Dari hasil penelitian menunjukkan bahwa kemunculan desainer grafis Kaliabu dapat ditelusuri mulai tahun 2012 terdapat sekitar dua orang warga Kaliabu yang berprofesi sebagai desainer grafis. Jika dilihat dari komposisi umur maka sekitar $15 \%$ berada pada kisaran 10-20 tahun yang masuk dalam kategori remaja. Selanjutnya, sekitar 76\% berada kisaran umur 20-30 tahun yang masuk dalam golongan pemuda. Sementara itu sekitar 9\% berada kisaran umur 30-40 tahun yang masuk dalam golongan tua desainer grafis Kaliabu. Pemuda memang menjadi bagian dari kelompok sosial yang memiliki kedekatan dengan kreativitas. Oleh sebab itu, tidak heran desainer grafis Kaliabu diisi oleh golongan pemuda. Berikut ilustrasi tabel mengenai jumlah dan komposisi desainer grafis Kaliabu:

Tabel 1 Jumlah dan Komposisi Desainer Grafis Kaliabu

\begin{tabular}{|c|c|c|c|c|c|c|c|c|c|c|c|}
\hline \multirow[t]{2}{*}{ No } & \multirow[t]{2}{*}{ Dusun } & \multicolumn{2}{|c|}{$\begin{array}{c}\text { Jenis } \\
\text { Kelamin }\end{array}$} & \multicolumn{5}{|c|}{ Pendidikan } & \multicolumn{3}{|c|}{ Usia } \\
\hline & & $\mathrm{L}$ & $\mathrm{K}$ & SD & SMP & SMA & D3 & S1 & $\begin{array}{l}10-20 \\
\text { tahun }\end{array}$ & $\begin{array}{l}20-30 \\
\text { tahun }\end{array}$ & $\begin{array}{l}30-40 \\
\text { Tahun }\end{array}$ \\
\hline 1 & Losari & 35 & 0 & 0 & 23 & 11 & 0 & 1 & 3 & 25 & 7 \\
\hline 2 & Demangan Barat & 20 & 0 & 0 & 14 & 5 & 0 & 1 & 2 & 17 & 1 \\
\hline 3 & Demangan Timur & 23 & 0 & 0 & 10 & 12 & 1 & 0 & 4 & 17 & 2 \\
\hline 4 & Ngampel & 44 & 0 & 2 & 20 & 14 & 0 & 0 & 5 & 36 & 3 \\
\hline 5 & Kantor & 30 & 0 & 0 & 15 & 15 & 0 & 1 & 7 & 20 & 3 \\
\hline 6 & Kopen & 27 & 0 & 0 & 16 & 21 & 1 & 0 & 3 & 20 & 4 \\
\hline 7 & Krajan & 19 & 0 & 2 & 7 & 10 & 0 & 0 & 4 & 15 & 0 \\
\hline \multirow[t]{2}{*}{8} & Jamblang & 17 & 0 & 0 & 3 & 14 & 0 & 0 & 3 & 14 & 0 \\
\hline & Jumlah & \multicolumn{2}{|c|}{212} & \multicolumn{5}{|c|}{215} & \multicolumn{3}{|c|}{215} \\
\hline
\end{tabular}

Sumber : Profil Desainer Grafis Kaliabu 2012

Komposisi desainer grafis Kaliabu dapat dilihat dari tingkat pendidikan. Jika dicermati maka kebanyakan mereka mendapat skill sebagai desiner grafis dari belajar secara otodidak. Sekitar $1 \%$ adalah lulusan SD. Mereka adalah generasi Kaliabu yang tidak memiliki kesempatan untuk bersekolah. Para desainer grafis Kaliabu dominan memiliki tingkat pendidikan SMP dan SMA. Desainer grafis dengan pendidikan 
SMP mencapai $49 \%$ kemudian golongan SMA mencapai $46 \%$. Sementara golongan Diploma dan S1 jika digabung hanya mencapai sekitar 4\%. Jika dicermati memang perkembangan skill desainer grafis Kaliabu tidak melaluiproses belajar formal. Akan tetapi, diperoleh dari proses belajar informal, dari satu orang ke orang yang lain dan bantuan teknologi informasi.

Dari keterangan mengenai kemunculan desainer grafis di Kaliabu dapat ditarik beberapa hal mengenai kontribusi pemuda dalam perkembangan desainer di Kaliabu. Pertama bahwa aktor yang menjadi agen perubahan di Kaliabu adalah seorang pemuda terdidik. Hal ini dapat dilihat dari peran Aqib sebagai pemuda yang mengembangkan profesi desiner Kaliabu pertama kali di Kaliabu. Kedua pemuda ini adalah kelompok masyarakat di Kaliabu yang paling dapat menyesuaikan dengan perkembangan berbagai sistem kerja saat ini. Hal ini dapat dilihat dari mayoritas umur desain grafis yang berada golongan kelompok pemuda. Ketiga dari apa yang terjadi di Kaliabu, dapat dilihat bahwa semua orang mempuyai potensi menjadi kelas kreatif. Hal ini dapat dilihat dari latar belakang para desainer di Kaliabu, meski hampir semua tidak memiliki latar belakang akademik sebagai seorag desainer grafis, namun setelah melakukan proses belajar secara informal, karya desainer Kaliabu dapat bersaing dengan para desainer grafis yang belajar melalui pendidikan formal

\subsubsection{Profil '3T' Wirausaha Muda Kreatif Kaliabu}

\subsubsection{Talenta}

Dalam konteks kelas kreatif, talenta adalah aspek yang paling membedakan kelas kreatif dan kelompok lain di masyarakat. Talenta adalah suatu kemampuan yang dimiliki individu untuk menciptakan hal-hal yang berguna dan mampu mendatangkan faedah ekonomi. Kemampuan menciptakan hal-hal baru diproses melalui kerja kreatif yang dilakukan oleh kelas kreatif. Florida mengungkapkan, jika Marx memandang bahwa sumber alat produksi adalah tanah, tambang, modal, perusahaan atau hal lain yang bersifat materil, maka pada kelas kreatif alat produksi utama bukan hal-hal itu, melainkan telenta yang melekat pada pikiran mereka. Dengan kata lain, alat produksi para kelas kreatif tidak bisa lepas dari dirinya.Hal ini juga berlaku bagi kelas kreatif di Kaliabu yaitu para desainer grafis Kaliabu. Desainer grafis adalah seseorang yang mampu menciptakan desain grafis. Kemampuan ini menjadi talenta utama desainer grafis Kaliabu.

Gambar 3. Desain Logo Desainer Kaliabu
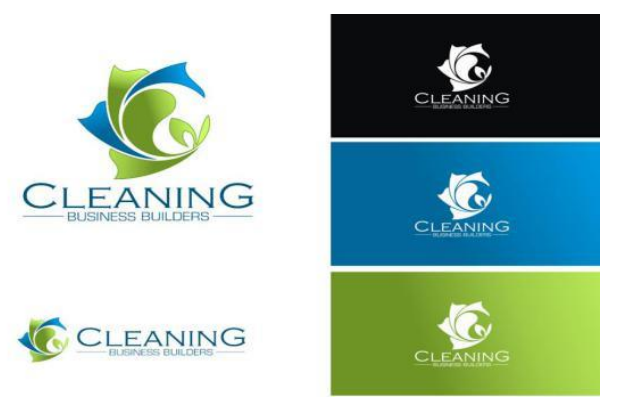

Sumber : Group Facebook Rewo-rewo

Desainer grafis sendiri juga memiliki banyak cabang spesifikasi. Khusus Desainer grafis Kaliabu mereka mengambil spesifikasi sebagai desainer grafis logo. Logo adalah suatu gambar yang menunjukkan identitas organisasi, institusi, atau kelompok yang diwakili. Didalam suatu gambar logo terdapat pesan yang disampaikan kepada setiap orang yang melihat logo tersebut. Menurut salah satu penggiat komunitas desainer grafis yaitu Abdul Bar, ia beranggapan bahwa para desainer grafis di Kaliabu sebenarnya lebih cocok disebut pengrajin logo. Sebutan ini setidaknya muncul karena dua alasan. Alasan pertama karena ia melihat hampir seluruh desain grafis di Kaliabu memilih untuk mengikuti kontes logo, bukan kontes desain yang lain.

Proses Kerja Desain Grafis Kaliabu 
Hampir semua desainer grafis di Kaliabu adalah desainer grafis dengan sistem kerja freelancer. Hal ini berarti mereka tidak terikat dengan kontrak kerja secara kaku. Mereka bisa memilih kapan mereka akan bekerja atau tidak. Kebanyakan mereka bekerja sebagai desainer grafis freelancer di salah satu situs internet yaitu 99design.com. Di situs ini terdapat sekitar ratusan hingga ribuan kontes desain grafis yang dapat diikuti. Pertama mereka harus mendaftar sebagai seorang desainer grafis 99design.com. Pendaftaran dilakukan dengan online dan cukup dengan modal memiliki alamat email. Setelah mendaftar mereka akan memiliki akun sebagai desiner grafis di 99design. Akun-akun ini biasanya menggunakan nama-nama samaran. Setelah memiliki akun sebagai desainer grafis di 99design.com. Mereka dapat melihat berbagai kontes desain grafis yang tersedia di 99design.com. Kontes-kontes ini merupakan kumpulan permintaan logo dari berbagai organisasi dan perusahaan yang masuk di 99design.com.

Gambar 4. Salah Satu Desainer Grafis Kaliabu

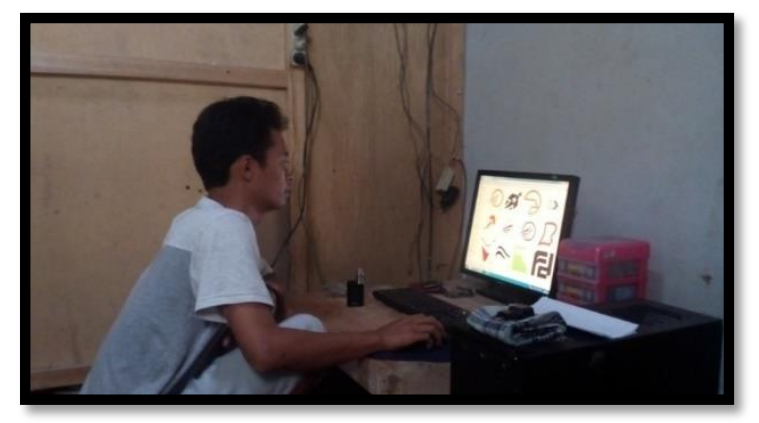

Sumber: Dokumentasi peneliti

Setelah memilih kontes yang sesuai dengan level dan ketertarikan mereka, kemudian mereka akan memahami brief kontes logo tersebut. Brief tersebut berisi keterangan kriteria kontes yang diminta oleh klien atau orang yang membutuhkan logo tersebut. Klien para desainer grafis sering disebut dengan istilah $\mathrm{CH}$ (Contest Holder). Setelah memahami brief tersebut kemudian mereka membuat logo sesuai dengan kriteria yang diminta dengan menggunakan aplikasi desain grafis di komputer.

Jika para desainer grafis Kaliabu menang, mereka akan mendapat pengumuman bahwa logo yang mereka kirim dipilih menjadi pemenang. Selanjutnya mereka berhak mendapat hadiah dari kontes yang mereka miliki. Nilai nominal kontes juga sangat bervariasi mulai 160 dolar sampai kontes yang mencapai ribuan dolar. Uang kemenangan tersebut kemudian dikirim melalui akun transaksi lintas negara seperti Paypal atau Westren Union. Akun ini digunakan untuk melakukan transaksi keuangan lintas negara. Uang tersebut kemudian dapat dicairkan dalam bentuk rupiah melalui bank-bank seperti BRI, BNI, BCA, ataupun Mandiri. Tergantung dimana mereka membuat akun Paypal mereka.

Jika dicermati hampir seluruh pekerjaan sebagai desainer grafis freelancer di 99design.com dapat dilakukan secara mandiri. Mulai dari mengerjakan kontes hingga mencairkan uang. Oleh karena itu, banyak dari mereka saat ini bekerja secara mandiri-mandiri. Namun demikian, bebeberapa di antara mereka biasanya juga membuatan logo, sekaligus menggunakan akun paypal bersama-sama dalam kelompok kecil. Pekerjaan mereka tidak diorganisasikan dalam kelompok besar. Hal ini karena, koordinasi dalam kelompok hingga ratusan orang justru akan mempersulit mereka. Biasanya koordinasi dalam kelompok besar antar-desainer grafis Kaliabu digunakan sebagai forum komunikasi dan pelatihan bersama saja.

\section{Pengembangan Talenta}

Pegembangan talenta desain grafis dilakukan dalam beberapa jalur. Pertama adalah melalui jalur pengembangan talenta secara langsung melalui interaksi yang terjadi antar-pemuda di Kaliabu. Kedua adalah melaui jalur otodidak yaitu dengan mempelajari berbagai informasi mengenai desain grafis yang ada di internet secara 
mandiri. Selain itu, pengembangan talenta secara otodidak juga terasah seiring lamanya pengalaman bekerja sebagai desain grafis. Ketiga pengembangan talenta dilakukan dengan melakukan pelatihan, yaitu dengan mendatangkan para profesional untuk memberikan pelajar mengenai desain grafis di Kaliabu. Keempat pengembangan talenta biasanya juga dilakukan melalui pertukaran informasi lewat jejaring sosial di media sosial dengan desainer grafis di luar Kaliabu.

\subsubsection{Teknologi}

Sebagai seorang desainer grafis setidaknya ada beberapa teknologi utama yang menunjang perkerjaan para desainer di Kaliabu. Berikut adalah beberapa teknologi utama yang harus dimiliki oleh seorang desainer: pertama adalah Perangkat komputer. Teknologi ini dibagi menjadi dua yaitu hardware dan software. Khusus bagi para desainer grafis di Kaliabu, aplikasi paling sering dipakai adalah Corel Draw. Melalui aplikasi ini mereka membuat logo yang diikut sertakan dalam kontes logo. Pemakaian Corel Draw juga tidak lepas dari spesifikasi bidang desain grafis yang digeluti para deesainer grafis di Kaliabu. Hampir semua desainer grafis di Kaliabu memilih spesifikasi sebagai desainer logo. Bagi para desainer grafis di Kaliabu aplikasi Corel Draw sangat cocok untuk membuat desain. Selain itu situs web yang menyediakan kontes logo juga mengharuskan desain grafis dibuat menggunakan corel draw.

"Teknologi yang membantu kami dalam bekerja adalah seperangkat komputer dan akses internet" (Haki, wawancara 2016)

Kedua adalah teknologi berupa akses internet. Keberadaan akses internet hal yang sangat mutlak bagi mereka. Oleh karena itu, saat salah satu dirjen KEMINFO (Kementerian Komikasi dan Informatika Republik Indonesia) datang mengunjungi Kaliabu, mereka berharap pemerintah dapat membantu dengan mempermudah akses internet di Kaliabu. Permintaan desainer grafis di Kaliabu akhirya dipenuhi oleh pemerintah. Melalui kementrian tersebut akhirya pemerintah membangun tower Speedy di Kaliabu. Hal ini mempermudah para desainer Kaliabu dalam mengakses internet. Kombinasi antara perangkat komputer dan akses internet ini menjadi suatu kesatuan teknologi yaitu Information and Communication Technology (ICT). Di Kaliabu, ICT secara spesifik memiliki fungsi sebagai berikut: pertama ICT sebagai alat bantu untuk mengembangkan talenta desainer grafis. Kedua ICT sebagai alat bantu para desainer grafis untuk mendapatkan akses terhadap pasar, dan ketiga, ICT sebagai alat bantu para desainer dalam membangun jaringan.

\subsubsection{Toleransi}

Jika dicermati salah satu aspek yang penting dalam kemunculan desainer grafis di Kaliabu adalah adanya sikap toleransi dan solidaritas pada desainer grafis Kaliabu. Toleransi adalah sikap menerima dan menghormati perbedaan. Sikap ini sangat penting bagi para pekerja seni. Sebagai seorang desainer grafis, mereka akan bertemu dengan berbagai macam klien. Apalagi dalam konteks desain grafis di Kaliabu, klien mereka justru lebih banyak yang berasal dari luar negeri. Oleh karena itu, sikap keterbukaan dan toleransi menjadi penting untuk dimiliki para desainer grafis di Kaliabu, sebagaimana dijelaskan:

"Kebanyakan Klien kami justru berasal dari luar negri" (Haki, wawancara 2016)

Selama ini mereka mengerjakan berbagai permintaan logo perusahaan dari luar negeri. Jadi mereka berinteraksi dengan orang-orang yang begitu beragam. Relasi yang mereka lakukan dalam konteks relasi klien dan penyedia jasa desain grafis. Menurut mereka, tidak ada permasalahan selama ini untuk bekerja dengan siapapun. Justru bertemu orang yang berbeda akan menambah pengetahuan dan pengalaman bagi mereka. Namun demikian, ada beberapa 
hal yang tidak bisa mereka lakukan dalam pekerjaannya sebagai desainer grafis. Mereka mengaku tidak akan membuat logo jika logo-logo tersebut berbenturan dengan nilai-nilai agama, sebagaimana dijelaskan:

"Kami tidak banyak memilih-milih kontes, jadi
sekiranya ada peluang untuk menang dan
mudah dikerjakan maka akan kami kerjakan,
tapi khusus untuk logo-logo seperti komunitas
klub homo atau lesbian kami tidak kerjakan.
Masih banyak pekerjaan dari kontes lain yang
tidak berbenturan dengan agama yang bisa
dikerjakan" (Haki, wawancara 2016)

Ungkapan Haki menunjukkan batas toleransi yang mereka miliki. Toleransi yang mereka praktekkan adalah toleransi yang dibatasi oleh nilai-nilai yang mereka ikuti. Mereka juga memiliki keyakinan bahwa pekerjaan yang membawa kebaikan adalah pekerjaan yang (dianggap) tidak melanggar batas-batas norma agama. Hal ini menunjukan bahwa toleransi yang mereka miliki dibatasi oleh nilai-nilai yang mereka anut.

\section{KESIMPULAN}

Hasil penelitian ini menunjukkan bahwa desainer grafis Kaliabu merupakan bagian dari kelas kreatif. Kesempatan berupa profesi desainer grafis yang hadir sering dengan adanya arus perubahan sistem sosial ekonomi, dimanfaatkan dengan maksimal oleh generasi muda Kaliabu. Dengan gairah eksplorasi yang tinggi para pemuda Kaliabu belajar secara otodidak untuk menjalankan profesi desainer grafis. Proses ini ternyata berhasil dan menginspirasi pemuda yang lain, akhinrya pada tahun 2012 di Kaliabu sudah ada ratusan penduduk muda Kaliabu yang menjadi seorang desainer grafis. Kesimpulan dari penelitian ini menunjukkan bahwa kemunculan kelas kreatif berupan ratusan desainer grafis di Kaliabu merupakan hasil dari dinamika pemuda Kaliabu dalam merespon perubahan sosial ekonomi saat ini. Kedua hal ini menjadi faktor eksternal dan internal munculnya kelas kreatif di Kaliabu.
Kekurangan dari penelitian ini hanya berfokus pada kemunculan kelas kreatif di Kaliabu. Oleh karena itu penting dilakukan penelitian selanjutnya terkait dengan aspek keberlanjutan keberadaan kelas kreatif di Kaliabu. Penelitian selanjutnya perlu mengidentifikasi aspek-aspek yang membuat kelas kreatif tetap eksis dan mengidentifikasi pula aspek-aspek yang membuat hilangya kelas kreatif. Peneliti berasumsi bahwa kelas kreatif memang selalu ada namun fungsi seseorang sebagai kelas kreatif bisa jadi hilang dari seseorang. Oleh karena itu, mengidentifikasi aspek-aspek yang terkait keberlanjutan keberadaan kelas kreatif penting untuk dilakukan.

\section{DAFTAR PUSTAKA}

Ash-amin, dkk (ed). 1994. Post-fordism a reader. Oxford: Blackwell publisher.

Azca, M. Najib dkk (ed). 2014. "Buku panduan studi kepemudaan: teori, metodologi, dan isu-isu kontemporer". Yogyakarta: Yousure.

Florida, Richard. 2002. The rise of creatve class. New York: Oxford University Press.

Giddens, Anthony. 2009. Sociology $6^{\text {th }}$ edition. Cambridge: Polity Press.

Matthew B.Miles dan A.Michael Huberman. 2009. Analisa data Kuanlitatif : Buku sumber tentang metode-metode baru. Jakarta: UI-Press.

Mauled Moelyono. 2010. Menggerakkan Ekonomi Kreatif Antara Tuntutan Dan Kebutuhan. Jakarta: Rajawali pers

Patilima, Hamid. 2005. Metode Penelitian Kualitatif. Jakarta: Alafabeta.

Suharman dkk (ed). 2008. Bunga RampaIi pemikiran pedesaan 2002-2008. Yogyakarta: Pusat Studi Pedesaan dan Kawasan. 
Sutopo dan Najib. 2013. "Transisi Pemuda Yogyakarta Menuju Dunia Kerja: Narasi dan Perspektif dari Selatan". Jurnal Universitas Paramadina 10 (2).

Rais, Muhammad Amin. 2008. AgendaAgenda Mendesak Bangsa Selamatkan Indonesia. Yogyakarta: PPSK Press.

Yin, Robert K. 1996. Studi Kasus Desain dan Metode. Jakarta: PT. Grafindo Permai.

Yuliastantu, Ana. 2008. Bekerja Sebagai Desainer Grafis. Jakarta: Penerbit Erlangga.

“Kecamatan Salaman dalam angka”. 2016. Badan Pusat Statistik Kabupaten Magelang. Diakses pada 20 Juni 2017. (https://magelangkab.bps.go.id/)

“Statitik kecamatan salaman”. 2016. Badan Pusat Statistik Kabupaten Magelang. Diakses pada 20 Juni 2017. (https://magelangkab.bps.go.id/linkTa belStatis/view/id/92)

“Kabupaten Magelang dalam Angka”. 2015. Badan Pusat Statistika. Diakses pada 25 Juni (https://magelangkab.bps.go.id/webb eta/website/pdf publikasi/KabupatenMagelangDalam-Angka-2015.pdf)

"Studi Pemetaan Industri Kretif". 2007. Departemen Perdagangan Republik Indonesia.

"Penduduk Kaliabu menurut Pekerjaan 20142015”. 2016. Dirjen Kependudukan dan Pencatatan Sipil.

"Penduduk Kaliabu menurut Pendidikan 2014-2015”. 2016. Dirjen Kependudukan dan Pencatatan Sipil.

"Perkembangan Desain Grafis di Indonesia. 2014. Diakses pada 25 Juni 2017. (http://www.idseducation.com/article s/perkembangan-desain-grafis-diindonesia/)

"Riak-Riak Desain Grafis Indonesia 1970Sekarang" (http://dgiindonesia.com/riak-riak-desain grafisindonesia-1970-sekarang/)

https://99designs.com/contests 